\section{Regards sur l'économie allemande}

Bulletin économique du CIRAC

83 | 2007

Varia

\title{
Histoire de la social-démocratie
}

GREBING Helga, Geschichte der deutschen Arbeiterbewegung. Von der Revolution 1848 bis ins 21. Jahrhundert

\section{(2) OpenEdition}

\section{Journals}

Édition électronique

URL : http://journals.openedition.org/rea/429

DOI : $10.4000 /$ rea.429

ISBN : 978-2-8218-0862-1

ISSN : 1965-0787

Éditeur

CIRAC

Édition imprimée

Date de publication : 1 octobre 2007

ISSN : 1156-8992

Référence électronique

" Histoire de la social-démocratie », Regards sur l'économie allemande [En ligne], 83 | octobre 2007, document 4, mis en ligne le 22 avril 2008, consulté le 21 septembre 2020. URL : http://

journals.openedition.org/rea/429; DOI : https://doi.org/10.4000/rea.429

Ce document a été généré automatiquement le 21 septembre 2020.

(C) CIRAC 


\section{Histoire de la social-démocratie}

GREBING Helga, Geschichte der deutschen Arbeiterbewegung. Von der Revolution 1848 bis ins 21. Jahrhundert

\section{RÉFÉRENCE}

GREBING Helga, Geschichte der deutschen Arbeiterbewegung. Von der Revolution

1848 bis ins 21. Jahrhundert, Vorwärts Buch, Berlin, 2007, 326 p.

Cette histoire de la social-démocratie allemande est une nouvelle édition, entièrement revue et actualisée jusqu'en 2000, du grand classique de la célèbre historienne Helga Grebing. Elle retrace l'évolution du mouvement ouvrier (partis et syndicats) et montre comment, à travers une histoire sociale et politique allemande mouvementée, ce dernier n'a cessé de lutter pour la promotion de la dignité ouvrière et la défense des droits sociaux fondamentaux. Ceci l'a conduit à privilégier, aux échéances décisives du $\mathrm{XX}^{\mathrm{e}}$ siècle, une action réformatrice responsable, par laquelle il a éminemment contribué à faire prévaloir, aussi bien dans l'opposition résolue que dans l'exercice difficile du pouvoir, à la fois la justice sociale et la liberté, le progrès économique et social et la démocratie politique. On lira avec intérêt les chapitres consacrés aux décennies 80 et 90 dans lesquelles l'auteur évalue avec sympathie et lucidité critiques l'action du SPD et des syndicats et s'interroge sur ce qui reste de la substance du " socialisme démocratique » face aux défis de la société du XXI siècle. $(\mathrm{rl})$ 